\title{
Seasonal generation and composition of garden waste in Aarhus (Denmark)
}

\author{
Boldrin, Alessio; Christensen, Thomas Højlund
}

Published in:

Waste Management

Link to article, DOI:

10.1016/j.wasman.2009.11.031

Publication date:

2010

Document Version

Peer reviewed version

Link back to DTU Orbit

Citation $(A P A)$ :

Boldrin, A., \& Christensen, T. H. (2010). Seasonal generation and composition of garden waste in Aarhus (Denmark). Waste Management, 30(4), 551-557. https://doi.org/10.1016/j.wasman.2009.11.031

\section{General rights}

Copyright and moral rights for the publications made accessible in the public portal are retained by the authors and/or other copyright owners and it is a condition of accessing publications that users recognise and abide by the legal requirements associated with these rights.

- Users may download and print one copy of any publication from the public portal for the purpose of private study or research.

- You may not further distribute the material or use it for any profit-making activity or commercial gain

- You may freely distribute the URL identifying the publication in the public portal

If you believe that this document breaches copyright please contact us providing details, and we will remove access to the work immediately and investigate your claim 


\title{
SEASONAL GENERATION AND COMPOSITION OF GARDEN WASTE IN AARHUS (DENMARK)
}

\author{
Alessio Boldrin, Thomas H. Christensen \\ Department of Environmental Engineering \\ Technical University of Denmark \\ Kongens Lyngby, Denmark
}

"NOTE: this is the author's version of a work that was accepted for publication in Waste Management journal. Changes resulting from the publishing process, such as peer review, editing, corrections, structural formatting, and other quality control mechanisms may not be reflected in this document. Minor changes may have been made to this manuscript since it was accepted for publication.

A definitive version is published in Waste Management, vol 30, pp 551-557, 10.1016/j.wasman.2009.11.031" 


\begin{abstract}
Garden waste generation and composition were studied in Aarhus, Denmark. The amount of garden waste generated varied seasonally, from $2.5 \mathrm{~kg}$ person ${ }^{-1}$ month $^{-1}$ in winter to $19.4 \mathrm{~kg}$ person ${ }^{-1}$ month $^{-1}$ in summer. Seasonal fractional composition and chemical characterization of garden waste were determined by sorting and sampling garden waste 8 times during one year. On a yearly basis, the major fraction of garden waste was "small stuff" (flowers, grass clippings, hedge cuttings and soil) making up more than $90 \%$ (wet waste distribution) during the summer. The woody fractions (branches, wood) are more significant during the winter. Seasonal trends in waste chemical composition were recorded and an average annual composition of garden waste was calculated, considering the varying monthly generation and material fraction composition: the wet garden waste contained $40 \%$ water, $30 \%$ organic matter (VS) and $30 \%$ ash. The ash content suggests that the garden waste contains a significant amount of soil. This is in particular the case during summer. Of nutrients, the garden waste contained in average on a dry matter basis $0.6 \% \mathrm{~N}$, $0.1 \% \mathrm{P}$, and $1.0 \% \mathrm{~K}$. However, the contents varied significantly among the fractions and during the year. The content of trace elements $(\mathrm{Cd}, \mathrm{Cr}, \mathrm{Cu}, \mathrm{Hg}, \mathrm{Ni}, \mathrm{Pb}$, and $\mathrm{Zn})$ was low.
\end{abstract}

Keywords: garden waste, material fraction, chemical characterization, seasonal composition 


\section{Introduction}

Garden and park waste is generated during maintenance of private gardens and public parks. It consists of organic (e.g. grass clippings, hedge cuttings, prunings, leaves, and wood) and inorganic (e.g. soil and stones) materials. Because of its origin, garden waste is expected to have variable generation rates and composition, depending on factors such as seasons and location (e.g. climate, urbanization, and waste management strategies). By definition, garden waste exists only when collected.

Little data and statistics are available regarding garden waste generation. In many European countries garden waste is collected mixed with food waste and data on generation rates for these two waste fractions, thus, often are confounded (Eurostat, 2005).

Composition of garden waste is reported in a few studies. Ham \& Komilis (2003) and Benito et al. (2005) presented a single characterization of garden waste for USA and Spain, respectively, while Williams (2005) reported on characterization of several material fractions. In these studies, the focus was on the parameters characterizing the organic fraction (Volatile Solids (VS), C, N, and C/N contents). Bary et al. (2005) sampled garden waste five times during spring and summer at four different composting facilities in the USA. The analytical results included a broad range of physical-chemical parameters and showed compositional variation among the facilities. The study concluded that grass clippings were the main source of variation. Ward et al. (2005) collected each month for a whole year garden waste samples from 9 different composting facilities in the UK and determined Dry Matter (DM), $\mathrm{Cl}, \mathrm{N}, \mathrm{C}$, and $\mathrm{K}$ contents as well as the $\mathrm{C} / \mathrm{N}$ ratio. The study showed seasonal patterns for some parameters ( $\mathrm{N}$ and $\mathrm{K}$ ).

Sampling and characterization of garden waste is particularly difficult because of its strong seasonality and heterogeneity. But a precise characterization of the different material fractions of garden waste is needed for assessing the environmental benefit of a differentiated management, for example, of woody parts for energy utilization and introduction of home composting for small fractions of garden waste.

The aim of this study was to determine the seasonal variability of garden waste generation, material fraction composition and chemical composition in Aarhus, the second largest city in Denmark (about 300,000 inhabitants).

\section{Methodology}

The amount of garden waste generated in Denmark is recorded by the Danish Environmental Protection Agency (Miljøstyrelsen) and included in the Affaldstatistik (Waste statistics), which is published annually. Data were taken from Affaldstatistik (2008).

Seasonal variability of the garden waste generation rate was determined using data for Aarhus, a city located on the east coast of the Jutland peninsula $\left(56^{\circ} 9^{\prime}\right.$ $0^{\prime \prime} \mathrm{N}, 10^{\circ} 12^{\prime} 0^{\prime \prime} \mathrm{E}$ ). Forests surround the city and several green areas are found within the urban area. Many households, especially in the residential areas, have a garden. All garden waste generated in Aarhus is collected at six recycling centres, located in the urban area, and treated at one composting plant, where each truck load entering the facility is weighted and recorded. 
Garden waste fractional and chemical compositions were determined during a one-year long sampling campaign at the composting plant. Garden waste was sampled eight times, twice per season (winter, spring, summer, fall). All the waste received at the facility at the day of the sampling (15-22 tonnes) was used as primary lot for the sampling. The garden waste was sorted into five material fractions: "Wood", "branches" (with leaves), "stones", and "foreign objects" (such as plastic bags) were sorted out manually or by means of a mechanical grab, while the fifth fraction "small stuff" was the remaining fraction. The large fractions (constituting more than $99.6 \%$ of the garden waste) "wood", "branches" and "small stuff" were subject to four particle size and mass reduction steps performed with systematic sampling frequencies in order to obtain representative samples of a few grams for chemical analysis. The four steps included (details available in Boldrin et al., 2009a):

- Separate processing of each material fraction in an industrial shredder for particle size reduction and collection of increments from the outlet of the shredder by means of a front loader to obtain a primary sample;

- Processing of each of the primary samples (3) in a shredder (ARP SC 2000, Brovst, Denmark) for particle size reduction and collection of increments from the outlet of the shredder by means of shovels to obtain a secondary sample;

- Laying of the secondary samples in elongated 1-D multilayer piles and collection of a tertiary sample by removal of cross-cut portions of the lot;

- Drying of the material at $105^{\circ} \mathrm{C}$ for 24 hours, shredding using a $1.0 \mathrm{~mm}$ bottom sieve and preparation of a laboratory sample by means of a riffle splitter (Rationel Kornservice RK12, Esbjerg, Denmark).

The laboratory samples of garden waste were sent to a certified external lab (ALS Scandinavia AB, Luleå, Sweden) for acid digestion and subsequent chemical analysis by means of ICP technique. The analytical method is described in details in Boldrin et al. (2009a). An overview of the sampling and analytical procedures can be found in Table 1. Chemical analyses were performed on three garden waste fractions (i.e. "small stuff", branches, wood). Because of their relatively small contribution $(<0.2 \%)$, the chemical composition of "foreign objects" and "stones" was not determined.

The sampling/analytical method was validated during one of the sampling event: 13 samples of the fraction "small stuff" were collected according to a reduced sampling scheme (also called staggered design) and variance across the samples was analysed. Statistics showed that none of the mass reduction steps introduced significant uncertainty and that the sampling method was robust for all the parameters considered. The representative sampling method is described in details in Boldrin et al. (2009a). Cumulative uncertainty due to both sampling and analytical errors was calculated and is reported as Coefficient of Variation (CV) in Table 3. It can be seen that such uncertainty is comparatively much smaller than the variation (standard deviation in Table 3) seen in the samples due to seasonal changes. It was concluded that the sampling method was accurate and suitable for studying seasonal variation in garden waste composition. 
Table 1 - Details of sampling operation and analytical procedures (from Boldrin et. al., 2009a).

\begin{tabular}{|c|c|c|}
\hline Phase & Description & Notes \\
\hline Sorting & Hydraulic grab & $\begin{array}{l}\text { Five material fractions: small stuff, } \\
\text { wood, branches, stones, foreign } \\
\text { objects }\end{array}$ \\
\hline \multirow[t]{4}{*}{ Sampling } & $\begin{array}{l}\text { Step 1: increments collected from 1-D outlet } \\
\text { of industrial shredder }\end{array}$ & From $10-30$ tonnes to $1-3$ tonnes \\
\hline & $\begin{array}{l}\text { Step 2: increments collected from 1-D outlet } \\
\text { of trailer shredder }\end{array}$ & From $1-3$ tonnes to $50-70 \mathrm{~kg}$ \\
\hline & Step 3: cross-cut increments collected from 1- & From $50-70 \mathrm{~kg}$ to $3-5 \mathrm{~kg}$ \\
\hline & D multilayer pile & \\
\hline Drying/ & Drying at $105^{\circ} \mathrm{C}$ for 24 hours, shredding with & \\
\hline grinding & $1.0 \mathrm{~mm}$ sieve & \\
\hline Sampling & Riffle splitter & From $1-3 \mathrm{~kg}$ to $5-10 \mathrm{~g}$ \\
\hline \multirow[t]{4}{*}{ Analyses } & $\mathrm{C}, \mathrm{H}, \mathrm{N}$ : Leco-600 & *ASTM D-3178-79 \\
\hline & F,Cl: Dionex ICS-90 & *SS 187185 \\
\hline & LHV: ISO 1928 & \\
\hline & $\begin{array}{l}\text { Metals: acid digestion ( } 5 \mathrm{ml} \mathrm{HNO}+0.5 \mathrm{ml} \\
\mathrm{H}_{2} \mathrm{O}_{2}+0.03 \mathrm{ml} \mathrm{HF} \text { ), ICP-SFMS and ICP-OES }\end{array}$ & $\begin{array}{l}\text { Microwave-assisted digestion, } 600 \mathrm{~W} \text {, } \\
\text { temperature } 140^{\circ} \mathrm{C}, \mathrm{P}<1400 \mathrm{kPa}, 1 \mathrm{~h}\end{array}$ \\
\hline
\end{tabular}

\section{Results}

\subsection{Seasonal garden waste generation}

Generation of garden waste in Denmark is presented in Figure 1 for the period 19942006. The amount of garden waste generated per-capita in Denmark has more than doubled during the considered period, from $67 \mathrm{~kg} \mathrm{person}^{-1}$ year $^{-1}$ in 1994 to $143 \mathrm{~kg}$ person $^{-1}$ year $^{-1}$ in 2006 . The difference between household generation and total generation represents the amount of garden waste produced from the maintenance of public areas. The increase in garden waste generation - largely due to improved collection systems - is one of the main contributors to increased residential waste generation in Denmark in the period 1994-2002 (Skovgaard et al., 2005).

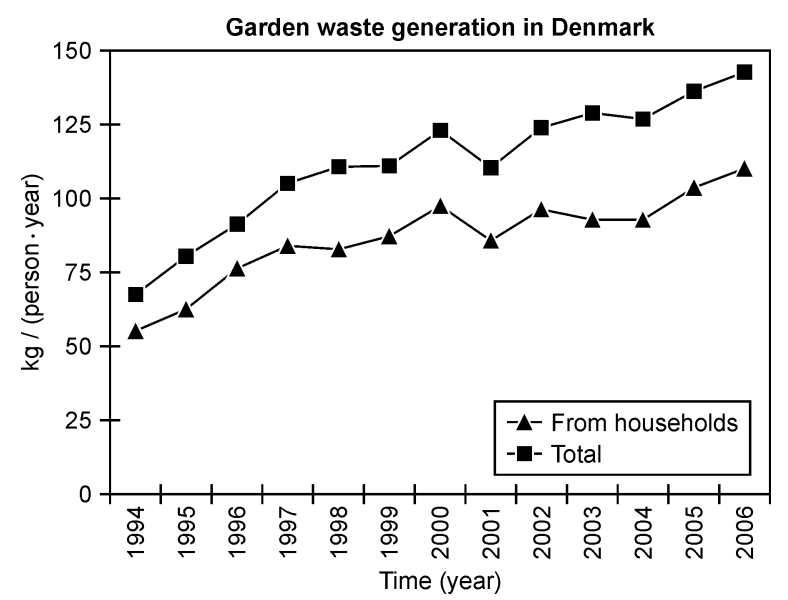

Figure 1 - Generation pro-capita of garden waste in Denmark in 1994-2006.

Figure 2 presents monthly generation rates $\left(\mathrm{kg} \mathrm{person}^{-1}\right.$ month $\left.^{-1}\right)$ of garden waste in Aarhus for the period 2003-2007. The figure shows clear and large variations in the amount of waste generated over the year. Most of the waste is produced in late spring (April to June) and during summer (maximum recorded is 
$19.4 \mathrm{~kg}$ person ${ }^{-1}$ month $^{-1}$ in July). Another peak can be seen in autumn (October) and it is probably due to collection of fallen leaves. Small amounts of waste are collected during winter (minimum: $2.5 \mathrm{~kg}_{\text {person }}{ }^{-1}$ month $^{-1}$ ). Generation patterns are quite similar for the five years presented in Figure 2. On an annual basis, the generation rate of garden waste in Aarhus has been fluctuating around the national average in the period 2003-2007: 122 in 2003, 125 in 2004, 148 in 2005, 130 in 2006, and155 kg person $^{-1}$ year $^{-1}$ in 2007.

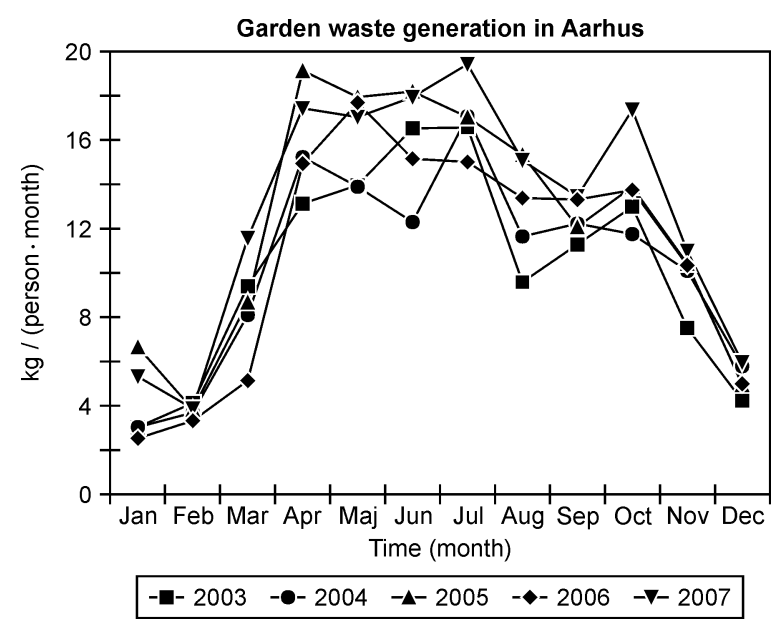

Figure 2 - Monthly amount of garden waste received at Aarhus composting plant in 2003-2007.

\subsection{Seasonal garden waste material fractions composition}

Figure 3 shows the material fraction composition of garden waste over one year. During summer (June to August) and fall (September to November) the predominant waste fraction is "small stuff", i.e. grass, soil, flowers, leaves, etc. In September this fraction accounts for more than $90 \%$ of the garden waste collected. In winter (December to April), garden waste contains a significant fraction of branches and wood (up to $45 \%$ ). This is due to the reduced activity in gardens in winter and the fact that focus is on tree and bush pruning. The results are in line with what is found in literature (for example in Ward \& Litterick, 2004). In all sampling events, the amount of stones and foreign objects found was very small, always below $0.2 \%$ of the total for both fractions. It is concluded that the presence of impurities in garden waste in Aarhus is very limited.

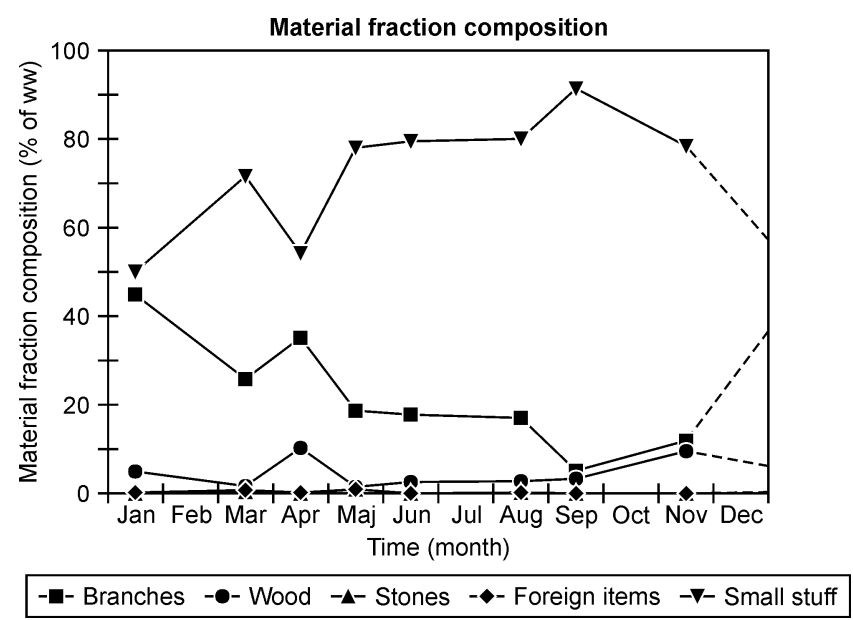

Figure 3 - Material fraction composition of garden waste over one year period at Aarhus composting plant. 
An annual material fraction composition is shown in Table 2. This composition was calculated as a weighted average, where the material fraction composition determined in each characterization event (Figure 3 ) contributed to the annual composition according to the monthly generation rate (Figure 2 ) reported for the specific month under consideration.

Table 2 - Yearly weighted average garden waste material fraction composition (wet weight).

\begin{tabular}{lc}
\hline Waste fraction & Material fraction (\%) \\
\hline Small stuff & 75.6 \\
Branches & 19.5 \\
Wood & 4.5 \\
Stones & $<0.2$ \\
Foreign items & $<0.2$ \\
\hline Total & 100 \\
\hline
\end{tabular}

\subsection{Seasonal material fractions chemical characterization}

Samples of each material fraction were analysed for more than 40 physical-chemical parameters. The original observations are not shown. Each fraction showed different seasonal patterns. While "wood" showed a relatively constant composition throughout the year, "small stuff" varied remarkably during the year. As shown in Figure 4, the ash content in "small stuff" fluctuated between $40 \%$ in fall (September to November) and $80 \%$ in late spring (May and June). The VS and C contents, the $\mathrm{C} / \mathrm{N}$ ratio and the Lower Heating Value (LHV) show all some seasonal variations. Almost all the other parameters have concentration patterns similar to the ash content. Such variations are probably due to both the type of organics present in the waste and the presence of soil.

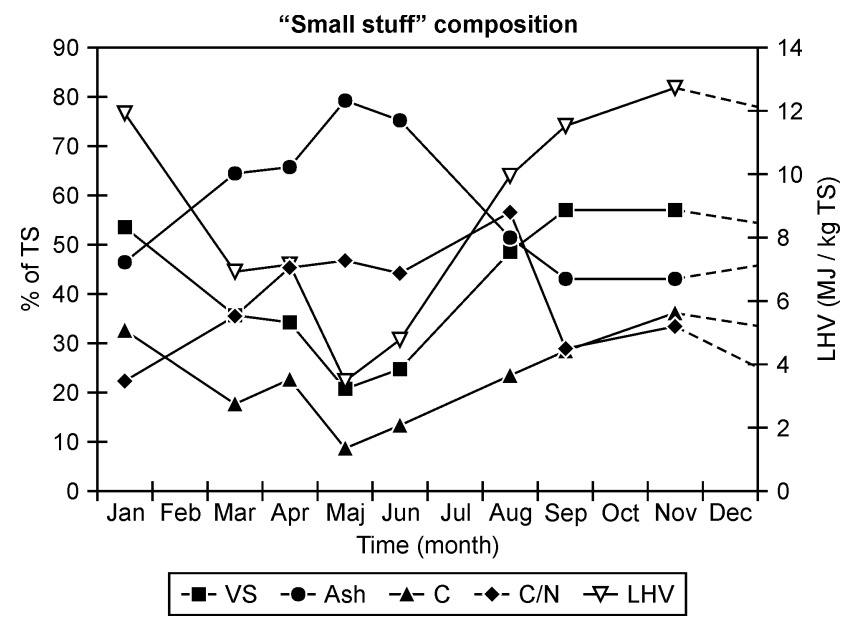

Figure 4 - Seasonal variation of VS, ash and C content, C/N ratio (left y-axis) and LHV in "small stuff" (right y-axis).

In "branches", the concentrations of most of the parameters were constant during the year (i.e. smaller range of variation) and several of them presented no particular variations. Results are reported in details in Boldrin et al. (2009b). 
Larger variations in "small stuff" than in "branches" were recorded during the year. One of the reasons could be the amount of grass clippings in garden waste, as reported by Bary et al. (2005).

\subsection{Seasonal garden waste chemical characterization}

Based on the material fraction distribution and the chemical characteristics of each fraction, a weighted average composition of garden waste was calculated for each sampling event, as presented in Table 3. The physical-chemical characteristic showed a seasonal dependence of the composition, according to the material fraction composition in a specific season. The seasonal variations of water, VS, and ash contents, and LHV (on wet weight basis) are presented in Figure 5. The VS content is higher in winter months (December to March), probably as results of less soil and grass turf in the waste. The VS content (and inversely ash content) and LHV seem to be clearly linked to each other, as it could be expected. The minimum LHV (on dry basis, not shown) is $6.35 \mathrm{GJ}^{\text {tonne }}{ }^{-1} \mathrm{TS}$ and was measured in late spring (May), when the "small stuff" is the main material fraction of garden waste (see Figure 3). As it will be explained later, "small stuff" likely contains a significant amount of soil (ash), which corresponds to a high ash content and a low LHV. The maximum LHV is 15.35 GJ tonne ${ }^{-1}$ TS and it was reached in wintertime (January), when the woody fractions ("Branches" and "Wood") were more frequent. The water content is higher in wintertime (November to March), probably due to the weather conditions (more rain, lower temperatures). No relation between water and ash contents could be clearly defined, mainly because of the dependence of the water content on the weather conditions present at the moment of sampling.

The contents of carbon (C) and nitrogen (N) also depend on the material fraction composition and have therefore also a seasonal dependence, as presented in Figure 6. The maximum C content was $40.1 \%$ of TS and was measured in winter (January), when the "wood" and "branches" fractions are more significant (see Figure 3 ). The minimum $C$ content ( $15.8 \%$ of TS) was measured in spring (May), when "small stuff" is the prevalent material fraction containing a lot of soil. The maximum nitrogen content was $0.76 \%$ of TS in late summer (September) and the minimum was $0.35 \%$ of TS in winter (March).

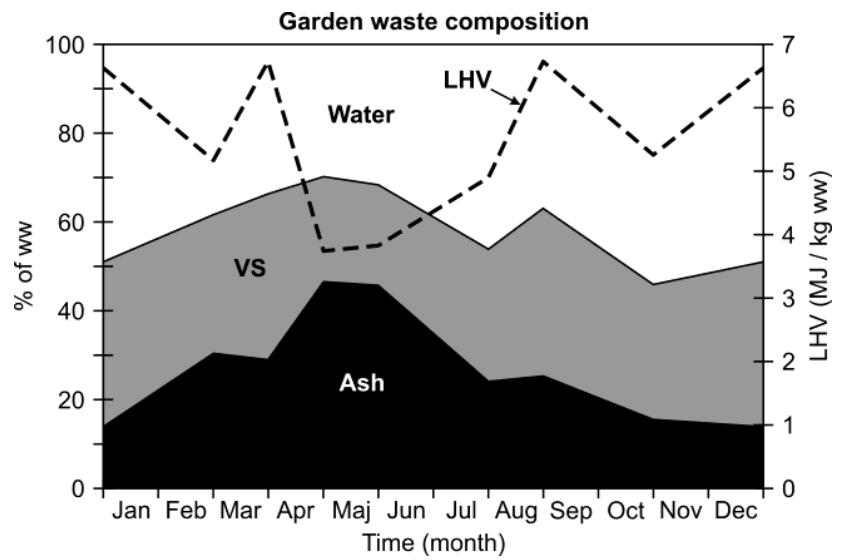

Figure 5 - Seasonal variation of the water, VS and ash content (left y-axis) and LHV of garden waste (on wet weight basis, right y-axis). The dotted line represents LHV. 
Table 3 - Seasonal characteristics of garden waste composted in Aarhus (2007).

\begin{tabular}{|c|c|c|c|c|c|c|c|c|c|c|c|}
\hline & Unit & January & March & April & May & June & August & September & November & Std. dev.* & CV (\%)** \\
\hline TS & $\%$ of ww & 51.1 & 61.7 & 66.5 & 70.3 & 68.5 & 54.1 & 63.2 & 46.0 & 8.8 & 1.7 \\
\hline VS & $\%$ of TS & 72.8 & 50.6 & 56.3 & 33.8 & 33.3 & 55.5 & 59.8 & 66.3 & 14.1 & 7.8 \\
\hline Ash & $\%$ of TS & 27.2 & 49.3 & 43.7 & 66.2 & 66.7 & 44.5 & 40.2 & 33.7 & 14.1 & 7.8 \\
\hline $\mathbf{S}$ & $\%$ of TS & 0.06 & 0.05 & 0.05 & 0.06 & 0.02 & 0.08 & 0.09 & 0.07 & 0.02 & 11 \\
\hline $\mathrm{Cl}$ & $\%$ of TS & 0.08 & 0.19 & 0.05 & 0.05 & 0.05 & 0.10 & 0.11 & 0.10 & 0.05 & - \\
\hline $\mathbf{F}$ & $\%$ of TS & $<0.01$ & $<0.01$ & $<0.01<$ & $<0.01$ & $<0.01$ & $<0.01<$ & $<0.01$ & $<0.01$ & 0.00 & - \\
\hline C-total & $\%$ of TS & 40.1 & 25.3 & 32.1 & 15.8 & 18.5 & 26.5 & 29.9 & 39.2 & 8.8 & 7.8 \\
\hline H & $\%$ of TS & 4.8 & 3.3 & 3.5 & 1.8 & 2.4 & 3.2 & 4.1 & 4.7 & 1.1 & - \\
\hline $\mathbf{N}$ & $\%$ of TS & 0.57 & 0.37 & 0.38 & 0.35 & 0.59 & 0.63 & 0.76 & 0.69 & 0.16 & 9.6 \\
\hline 0 & $\%$ of TS & 24.4 & 22.8 & 21.4 & 14.8 & 17.4 & 21.4 & 32.7 & 23.4 & 5.3 & - \\
\hline $\mathrm{C} / \mathrm{N}$ ratio & & 70 & 68 & 84 & 45 & 31 & 42 & 39 & 57 & 18 & - \\
\hline LHV & $\mathrm{MJ} / \mathrm{kg}$ TS & 15.3 & 9.9 & 11.4 & 6.3 & 6.7 & 11.2 & 12.1 & 14.3 & 3.2 & - \\
\hline Si & $\%$ of TS & 8.8 & 15 & 15 & 25 & 25 & 11 & 14 & 12 & 6.2 & 4.9 \\
\hline Al & $\%$ of TS & 0.7 & 1.2 & 1.3 & 2.3 & 2.2 & 1.2 & 1.4 & 1.1 & 0.52 & 4.4 \\
\hline $\mathrm{Ca}$ & $\%$ of TS & 1.1 & 1.4 & 1.1 & 2.0 & 1.2 & 1.3 & 1.2 & 1.1 & 0.30 & 8.9 \\
\hline $\mathrm{Fe}$ & $\%$ of TS & 0.31 & 0.60 & 0.54 & 0.94 & 0.97 & 0.52 & 0.62 & 0.57 & 0.22 & 6.6 \\
\hline K & $\%$ of TS & 0.53 & 0.69 & 0.86 & 1.2 & 1.4 & 1.0 & 1.2 & 0.72 & 0.30 & 6.6 \\
\hline Mg & $\%$ of TS & 0.10 & 0.15 & 0.13 & 0.23 & 0.22 & 0.18 & 0.20 & 0.13 & 0.05 & 6.2 \\
\hline$M n$ & $\%$ of TS & 0.01 & 0.02 & 0.02 & 0.03 & 0.03 & 0.02 & 0.02 & 0.02 & 0.01 & 15 \\
\hline $\mathrm{Na}$ & $\%$ of TS & 0.27 & 0.45 & 0.34 & 0.64 & 0.55 & 0.35 & 0.35 & 0.36 & 0.13 & 6.9 \\
\hline $\mathbf{P}$ & $\%$ of TS & 0.07 & 0.06 & 0.08 & 0.08 & 0.11 & 0.12 & 0.17 & 0.08 & 0.04 & 9.6 \\
\hline $\mathrm{Ti}$ & $\%$ of TS & 0.04 & 0.08 & 0.08 & 0.13 & 0.16 & 0.07 & 0.08 & 0.05 & 0.04 & 7.6 \\
\hline As & $\mathrm{mg} / \mathrm{kg} \mathrm{TS}$ & 1.3 & 2.0 & 2.6 & 2.2 & 2.7 & 2.2 & 3.6 & 2.9 & 0.68 & 9.0 \\
\hline $\mathrm{Ba}$ & $\mathrm{mg} / \mathrm{kg} \mathrm{TS}$ & 104 & 140 & 189 & 282 & 283 & 170 & 199 & 135 & 66 & 7.2 \\
\hline $\mathrm{Be}$ & $\mathrm{mg} / \mathrm{kg} \mathrm{TS}$ & 0.25 & 0.43 & 0.45 & 0.52 & 0.63 & 0.36 & 0.43 & 0.37 & 0.11 & 12 \\
\hline $\mathrm{Cd}$ & $\mathrm{mg} / \mathrm{kg}$ TS & 0.22 & 0.19 & 0.26 & 0.15 & 0.32 & 0.21 & 0.20 & 0.18 & 0.05 & 9.8 \\
\hline Co & $\mathrm{mg} / \mathrm{kg} \mathrm{TS}$ & 1.0 & 2.2 & 1.5 & 2.6 & 3.2 & 2.7 & 1.8 & 1.7 & 0.72 & 9.9 \\
\hline $\mathrm{Cr}$ & $\mathrm{mg} / \mathrm{kg}$ TS & 8.6 & 17 & 16 & 31 & 23 & 16 & 20 & 13 & 6.7 & 14 \\
\hline $\mathrm{Cu}$ & $\mathrm{mg} / \mathrm{kg} \mathrm{TS}$ & 7.4 & 10 & 9.3 & 11 & 17 & 14 & 13 & 11 & 3.2 & 14 \\
\hline $\mathrm{Hg}$ & $\mathrm{mg} / \mathrm{kg} \mathrm{TS}$ & $<<0.02$ & $<0.03$ & $<0.04$ & $<0.02$ & $<0.05$ & $<0.03$ & $<0.04$ & $<0.04$ & 0.01 & 18 \\
\hline Mo & $\mathrm{mg} / \mathrm{kg} \mathrm{TS}$ & $5<1.7$ & $<3.1$ & $<2.7$ & $<4.2$ & $<3.6$ & $<2.6$ & $<1.9$ & $<1.6$ & 0.92 & - \\
\hline $\mathrm{Nb}$ & $\mathrm{mg} / \mathrm{kg} \mathrm{TS}$ & $<1.8$ & $<15$ & $<2.6$ & $<4.1$ & $<4.2$ & $<2.6$ & $<1.9$ & $<1.6$ & 4.6 & - \\
\hline $\mathrm{Ni}$ & $\mathrm{mg} / \mathrm{kg} \mathrm{TS}$ & 2.0 & 4.6 & 3.5 & 4.9 & 5.1 & 4.7 & 3.5 & 3.7 & 1.0 & 8.1 \\
\hline $\mathrm{Pb}$ & $\mathrm{mg} / \mathrm{kg}$ TS & 5.2 & 7.3 & 6.1 & 7.4 & 12 & 11 & 8.7 & 8.0 & 2.3 & 12 \\
\hline Sb & $\mathrm{mg} / \mathrm{kg} \mathrm{TS}$ & 0.00 & 0.07 & 0.03 & 0.06 & 0.00 & 0.20 & 0.00 & 0.00 & 0.64 & 17 \\
\hline Sc & $\mathrm{mg} / \mathrm{kg} \mathrm{TS}$ & 0.87 & 1.4 & 1.2 & 3.0 & 1.9 & 1.5 & 1.3 & 1.4 & 4.3 & 5.4 \\
\hline Sn & $\mathrm{mg} / \mathrm{kg} \mathrm{TS}$ & $<<6.2$ & $<15$ & $<13$ & $<17$ & $<18$ & $<8.7$ & $<9.4$ & $<8.0$ & 18 & - \\
\hline $\mathrm{Sr}$ & $\mathrm{mg} / \mathrm{kg} \mathrm{TS}$ & 58 & 57 & 65 & 110 & 90 & 68 & 75 & 67 & 5.7 & 4.5 \\
\hline $\mathbf{v}$ & $\mathrm{mg} / \mathrm{kg}$ TS & 6.8 & 13 & 12 & 21 & 24 & 13 & 15 & 9.2 & 9.2 & 5.3 \\
\hline w & $\mathrm{mg} / \mathrm{kg} \mathrm{TS}$ & $<17$ & $<31$ & $<27$ & $<42$ & $<36$ & $<26$ & $<19$ & $<16$ & 2.8 & - \\
\hline$Y$ & $\mathrm{mg} / \mathrm{kg} \mathrm{TS}$ & 2.5 & 4.7 & 4.7 & 10 & 9.0 & 4.6 & 4.8 & 3.2 & 13 & 14 \\
\hline $\mathrm{Zn}$ & $\mathrm{mg} / \mathrm{kg} \mathrm{TS}$ & 58 & 51 & 40 & 54 & 63 & 84 & 66 & 69 & 67 & 15 \\
\hline $\mathrm{Zr}$ & $\mathrm{mg} / \mathrm{kg} \mathrm{TS}$ & 35 & 48 & 89 & 172 & 219 & 66 & 113 & 39 & 8.8 & 13 \\
\hline \multicolumn{12}{|c|}{$\begin{array}{l}\text { * Absolute value - calculated based on the mean value of the } 8 \text { samples. It describes the (seasonal) variability of the } \\
\text { samples. }\end{array}$} \\
\hline
\end{tabular}

Figure 6 also presents the development of $\mathrm{C} / \mathrm{N}$ ratio during the year. In summertime (June to September), the presence of nitrogen containing material (grass, flowers, etc.) is resulting in low $\mathrm{C} / \mathrm{N}$. In wintertime (December to April), the 
predominance of carbon containing material (wood, branches, etc.) enhances the $\mathrm{C} / \mathrm{N}$, that reaches 84 in April. The $\mathrm{C} / \mathrm{N}$ ratio is one of the key parameters for an efficient composting process. USEPA (1994) indicates an optimum $\mathrm{C} / \mathrm{N}$ value for composting between 25 and 35, while a ratio between 35 and 40 is reported in Golueke (1977) for woody feedstocks containing a significant fraction of lignin. The results suggest that in some periods of the year (particularly during winter November to April) the $\mathrm{C} / \mathrm{N}$ ratio is not optimal for the composting process.

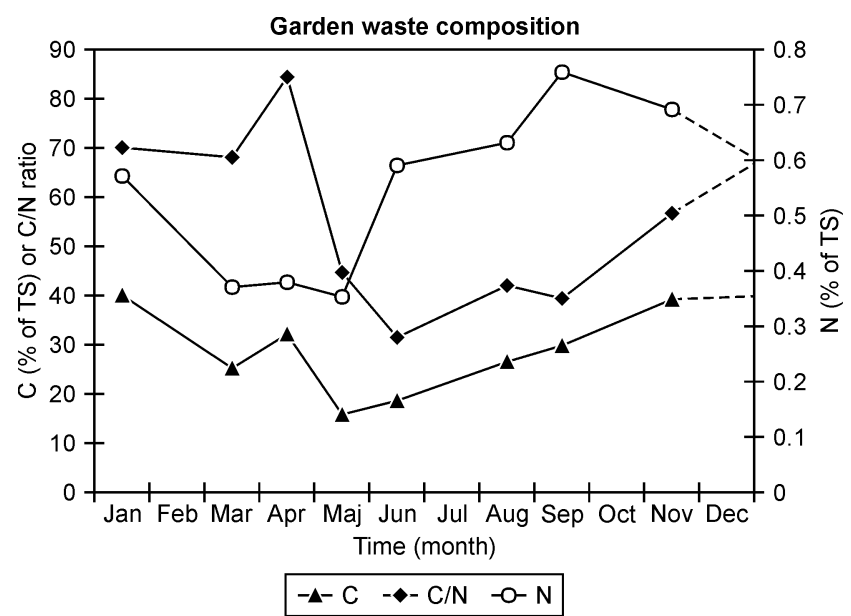

Figure 6 - Seasonal variation of carbon and nitrogen content, and $\mathrm{C} / \mathrm{N}$ ratio of garden waste. Please note different scales for $y$-axis.

Figure 7 presents seasonal concentration of $\mathrm{P}, \mathrm{K}, \mathrm{Cd}, \mathrm{Cu}$, and $\mathrm{Pb}$ (please note that unit of the $P$ concentration is $1 / 10$ and the unit of the $C d$ concentration is $1 / 100$ of the numerical values plotted in the graph). Similarly to most of the other macrocomponents (i.e. analytes reported in \% of TS), $\mathrm{P}$ and $\mathrm{K}$ seem to have a seasonal variation: low concentrations in winter (December to March) and higher concentrations in summer (June to September). A similar pattern can be seen for trace elements (i.e. analytes reported in $\mathrm{mg} / \mathrm{kg} \mathrm{TS}$ ), such as $\mathrm{Cu}$ and $\mathrm{Pb} . \mathrm{Cd}$ concentrations, instead, are fluctuating during the year, without showing a particular pattern.

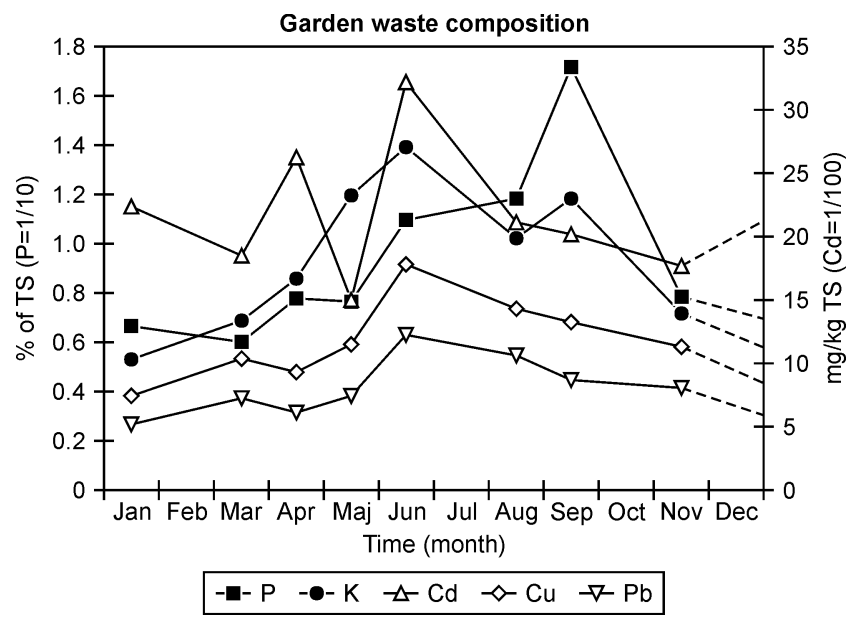

Figure 7 - Seasonal variation of the content of some analytes in garden waste. Please note different scales for $y$-axis (left for $\mathrm{P}, \mathrm{K}$ and right for $\mathrm{Cd}, \mathrm{Cu}, \mathrm{Pb}$ ). Furthermore, $\mathrm{P}$ concentration is $1 / 10$ and $\mathrm{Cd}$ concentration is $1 / 100$ of what reported in the chart. 


\subsection{Annual garden waste chemical characterization}

Combining data regarding generation rates, material fraction composition and chemical characterization of each single fraction, a weighted average garden waste characterization was calculated. Results are reported in Table 4 for the three material fractions analysed during the study.

\section{Discussion}

The study clearly showed a strong seasonal variation in garden waste composition. Correlations among the analysed parameters were studied with Pearson correlation analysis. The common standards suggested in Dahlen et al. (2009) were adopted for the interpretation of Pearson's correlation coefficients $\left(R^{2}\right)$ : up to 0.2 , the correlation is very weak; up to 0.5 , weak; up to 0.7 , medium; up to 0.9 , high; and up to 1 , very high.

The results of the Pearson's correlation analysis (matrix presented in Table 5) were used to define indicator elements, origin of some compounds, groups of compounds with similar behaviour, and compounds behaving uncorrelated from anything else.

Ash content is well correlated to most of the metals (both macrocomponents and trace elements). Ash can therefore be used as an indicator element for most of the non-volatile compounds when, for instance, doing a mass balance of garden waste composting. The definition and use of indicator substances is explained in details in Brunner \& Rechberger (2003).

Carbon and nitrogen have rather different behaviours. The carbon content is negatively correlated with all the macro-components and in particular with those parameters ( $\mathrm{Si}$ and $\mathrm{Al}$ ) present in the soil matrix. This indicates - as expected - that most of the carbon present in garden waste comes from organic material. The nitrogen content is instead neither correlated with any of the macro-components nor with VS, i.e. contributions to $\mathrm{N}$ content come from both soil and organic material.

All the macro-components, but $\mathrm{P}$, are well correlated with ash and with each other (especially with $\mathrm{Si}$ and Al). This may suggest that that these components are mainly brought in by soil. Phosphorous (P) and Potassium (K) show some peculiar behaviour. The $\mathrm{P}$ content is only correlated with $\mathrm{N}$ and $\mathrm{K}$ contents (high and medium respectively), i.e. it is not possible to conclude on the origin of $P$ (from soil, from organics, etc.). In both cases the correlations are positive - when $\mathrm{N}$ and $\mathrm{K}$ are high then also $P$ is high. The maximum concentrations of $P$ and $K$ are recorded in summer months (June to September, Figure 7). This is an important consideration to take into account when assessing the nutrient recovery potential from the garden waste. The $\mathrm{K}$ content is instead negatively correlated with VS content and positively correlated with the other macro-components, indicating that $\mathrm{K}$ is mainly introduced by soil. 
Table 4 - Yearly average characterization of garden waste in Aarhus Affaldscenter (accounting for more than $99.6 \%$ of generated amount of wet waste).

\begin{tabular}{|c|c|c|c|c|c|}
\hline & Unit & Small stuff & Branches & Wood & Garden waste \\
\hline TS & $\%$ of ww & 60.9 & 58.9 & 65.3 & 60.9 \\
\hline VS & $\%$ of TS & 41.5 & 82.4 & 89.2 & 51.7 \\
\hline Ash & $\%$ of TS & 58.5 & 17.6 & 10.8 & 48.3 \\
\hline $\mathbf{S}$ & $\%$ of TS & 0.07 & 0.04 & 0.03 & 0.06 \\
\hline $\mathrm{Cl}$ & $\%$ of TS & 0.11 & 0.07 & 0.04 & 0.10 \\
\hline $\mathbf{F}$ & $\%$ of TS & $<0.008$ & $<0.008$ & $<0.01$ & $<0.01$ \\
\hline C-total & $\%$ of TS & 21.6 & 42.0 & 46.0 & 26.8 \\
\hline H & $\%$ of TS & 2.7 & 5.1 & 5.9 & 3.3 \\
\hline $\mathbf{N}$ & $\%$ of TS & 0.62 & 0.43 & 0.20 & 0.56 \\
\hline 0 & $\%$ of TS & 18.3 & 35.0 & 41.3 & 22.5 \\
\hline $\mathrm{C} / \mathrm{N}$ ratio & & 35 & 105 & 230 & 57 \\
\hline Cal. value & $\mathrm{MJ} / \mathrm{kg}$ TS & 8.4 & 16.5 & 17.8 & 10.4 \\
\hline Si & $\%$ of TS & 19 & 5.5 & 3.7 & 16 \\
\hline Al & $\%$ of TS & 1.7 & 0.51 & 0.34 & 1.4 \\
\hline $\mathrm{Ca}$ & $\%$ of TS & 1.4 & 0.76 & 0.43 & 1.2 \\
\hline Fe & $\%$ of TS & 0.79 & 0.21 & 0.15 & 0.67 \\
\hline K & $\%$ of TS & 1.2 & 0.50 & 0.33 & 1.0 \\
\hline Mg & $\%$ of TS & 0.21 & 0.09 & 0.06 & 0.18 \\
\hline$M n$ & $\%$ of TS & 0.03 & 0.009 & 0.007 & 0.02 \\
\hline $\mathrm{Na}$ & $\%$ of TS & 0.49 & 0.16 & 0.10 & 0.41 \\
\hline $\mathbf{P}$ & $\%$ of TS & 0.12 & 0.07 & 0.04 & 0.11 \\
\hline $\mathrm{Ti}$ & $\%$ of TS & 0.11 & 0.03 & 0.02 & 0.09 \\
\hline As & $\mathrm{mg} / \mathrm{kg}$ TS & 2.7 & 0.55 & 9.2 & 2.6 \\
\hline $\mathrm{Ba}$ & $\mathrm{mg} / \mathrm{kg} \mathrm{TS}$ & 233 & 74 & 57 & 193 \\
\hline $\mathrm{Be}$ & $\mathrm{mg} / \mathrm{kg}$ TS & 0.54 & 0.16 & 0.10 & 0.44 \\
\hline $\mathrm{Cd}$ & $\mathrm{mg} / \mathrm{kg} \mathrm{TS}$ & 0.25 & 0.19 & 0.11 & 0.23 \\
\hline Co & $\mathrm{mg} / \mathrm{kg}$ TS & 2.8 & 1.1 & 0.44 & 2.3 \\
\hline $\mathrm{Cr}$ & $\mathrm{mg} / \mathrm{kg}$ TS & 21 & 8.3 & 13 & 18 \\
\hline $\mathrm{Cu}$ & $\mathrm{mg} / \mathrm{kg}$ TS & 15 & 6.0 & 9.0 & 13 \\
\hline $\mathrm{Hg}$ & $\mathrm{mg} / \mathrm{kg}$ TS & 0.04 & $<0.02$ & $<0.02$ & $<0.04$ \\
\hline Mo & $\mathrm{mg} / \mathrm{kg}$ TS & $<3.3$ & $<1.0$ & $<0.65$ & $<2.7$ \\
\hline $\mathrm{Nb}$ & $\mathrm{mg} / \mathrm{kg}$ TS & $<5.7$ & $<1.00$ & 0.60 & $<4.5$ \\
\hline $\mathrm{Ni}$ & $\mathrm{mg} / \mathrm{kg}$ TS & 5.3 & 1.5 & 0.96 & 4.4 \\
\hline $\mathrm{Pb}$ & $\mathrm{mg} / \mathrm{kg}$ TS & 12 & 2.2 & 1.7 & 9.6 \\
\hline Sb & $\mathrm{mg} / \mathrm{kg}$ TS & $<0.16$ & $<0.08$ & $<0.04$ & $<0.14$ \\
\hline Sc & $\mathrm{mg} / \mathrm{kg}$ TS & 1.8 & 0.49 & 0.32 & 1.5 \\
\hline Sn & $\mathrm{mg} / \mathrm{kg}$ TS & $<15$ & $<4.0$ & $<3.0$ & $<12$ \\
\hline $\mathrm{Sr}$ & $\mathrm{mg} / \mathrm{kg}$ TS & 864 & 37 & 25 & 661 \\
\hline V & $\mathrm{mg} / \mathrm{kg} \mathrm{TS}$ & 19 & 4.8 & 3.0 & 15 \\
\hline W & $\mathrm{mg} / \mathrm{kg}$ TS & $<33$ & $<10$ & $<6.0$ & $<27$ \\
\hline $\mathbf{Y}$ & $\mathrm{mg} / \mathrm{kg}$ TS & 6.8 & 2.0 & 1.1 & 5.6 \\
\hline Zn & $\mathrm{mg} / \mathrm{kg} \mathrm{TS}$ & 76 & 29 & 18 & 65 \\
\hline $\mathrm{Zr}$ & $\mathrm{mg} / \mathrm{kg}$ TS & 129 & 30 & 19 & 104 \\
\hline
\end{tabular}


Some of the trace elements of environmental concern $(\mathrm{Cd}, \mathrm{Cu}, \mathrm{Hg}, \mathrm{Pb}$, and $\mathrm{Zn}$ ) were all found in very low concentrations and their presence is not correlated to any of the other analytes. In particular, the concentrations of these metals are not linked to the $\mathrm{Si}$ and $\mathrm{Al}$ content, indicating that they are not brought in specifically with soil but are rather spread across all the material fractions. The presence of $\mathrm{Cr}$ and $\mathrm{Ni}$ seems instead to be linked to soil, as their concentrations show high to very high correlation with some of the macro-components present in soil. Concentrations of $\mathrm{Cr}, \mathrm{Cu}, \mathrm{Ni}, \mathrm{Pb}$, and $\mathrm{Zn}$ are in line with values reported in Bary et al. (2005).

\section{Conclusion}

Seasonal generation and composition of Danish garden waste was studied in the municipality of Aarhus. Garden waste generation is extremely variable during the year, from a minimum of $2.5 \mathrm{~kg}$ person ${ }^{-1}$ month $^{-1}$ in winter to a maximum of $19.4 \mathrm{~kg}$ person ${ }^{-1}$ month $^{-1}$ in summer. The material fraction distribution over the year (based on 8 samplings) showed a clear dominance of "small stuff" (flowers, grass clippings, hedge cuttings and soil) in summer (June to August), while woody fractions where more significant in winter (December to April). The chemical composition also showed some seasonal variation. The maximum VS and C concentrations and LHV were found in wintertime, when presence of woody materials was significant. Ash and metals content were higher in summer (June to September), when a lot of soil was present in the garden waste. Nitrogen peaked in the summer (up to $0.76 \%$ of TS in garden waste), when grass clippings were a major component of garden waste. The $\mathrm{C} / \mathrm{N}$ ratio was relatively high all year and, in the winter months, it was much higher than the recommended values for an optimal composting process. The nitrogen content was found both in the organic fraction and in the soil constituting a major part of the "small stuff".

\section{Acknowledgments}

The authors would like to thank Preben Stjernholm and Henrik Haalgard at Aarhus Affaldscenter for the time spent in planning and performing the sampling operations and for all the machineries they made available. Moreover, we would like to thank Jacob K. Andersen for his valuable help and dedication during the sampling campaign. 


\section{References}

Bary, A. I., Cogger, C.G., Sullivan, D.M., Myhre, E.A., 2005. Characterization of fresh yard trimmings for agricultural use. Bioresource Technology 96, 1499-1504.

Benito, M., Masaguer, A., Antonio, R., Moliner, A., 2005. Blending green feedstocks at a Madrid composting facility. BioCycle 46, 72-74.

Boldrin, A., Spliid, H., Christensen, T.H., 2009a. Method for fractional garden waste sampling and chemical analysis. Submitted to Science of the Total Environment.

Boldrin, A., Andersen, J.K., Christensen, T.H., 2009b. Miljøvurdering af haveaffald i Aarhus Kommune. (LCA report: Environmental assessment of garden waste management in Aarhus Kommune, in Danish). Department of Environmental Engineering, Technical University of Denmark, Kgs. Lyngby, Denmark.

Brunner, P.H., Rechberger. H., 2003. Practical Handbook of Material Flow Analysis. Published by CRC Press LCC, Florida, USA.

Dahlén, L., Åberg, H., Lagerkvist, A., Berg, P.E.O., 2009. Inconsistent pathways of household waste. Waste Management 29, 1798-1806.

Eurostat, 2005. Waste Generated and Treated in Europe: Data 1995-2003. Eurostat, Luxembourg.

Golueke, C.G., 1977. Biological Reclamation of Solid Wastes. Rodale Press, Emmaus, PA, USA.

Ham, R.K., Komilis, D.P., 2003. A Laboratory Study to Investigate Gaseous Emissions and Solids Decomposition During Composting of Municipal Solid Wastes. EPA-600/R03/004. U.S. Environmental Protection Agency, Washington, DC, USA. Accessed May 2009 from: http://www.epa.gov/nrmrl/pubs/600r03004/600r03004.pdf

Miljøstyrelsen. 2008. Affaldstatistik 2006. Orientering fra Miljøstyrelsen Nr. 22008 (Waste statistics 2006, in Danish. Data generated by the Danish EPA).

Skovgaard, M., Moll, S., Moller Andersen, F., Larsen, H., 2005. Outlook for waste and material flows. Baseline and alternative scenarios. ETC/RWM working paper 2005/1. European Topic Centre on Resource and Waste Management. Accessed April 2009 from: http://scp.eionet.europa.eu/announcements/ann1113909495

USEPA, 1994. Composting yard trimmings and municipal solid waste. EPA530-R-94003. US Environmental Protection Agency, 1994.

Ward, C., Litterick, A., 2004. Assessment of the potential variation of composted material across the UK - Literature review. WRAP, Banbury. 
Ward, C., Litterick, A., Stephen, N., 2005. Assessment of the potential for site and seasonal variation of composted material across the UK. WRAP, Banbury, UK.

Williams, P. T., 2005. Waste treatment and disposal. John Wiley and Sons Ltd, Chichester, UK. 




Table 5 - Results of the Pearson's correlation analysis. 
